\title{
PENGELOLAAN KEUANGAN DAN PENGEMBANGAN USAHA PADA USAHA MIKRO KECIL MENENGAH (STUDI KASUS PADA UMKM MADU HUTAN LESTARI SUMBAWA)
}

\author{
${ }^{1}$ Muhammad Sabiq Hilal Al Falih, ${ }^{2}$ Reza Muhammad Rizqi, ${ }^{3}$ Nova Aditya Ananda \\ ${ }^{1 *}$ Fakultas Ekonomi dan Bisnis Universitas Teknologi Sumbawa \\ ${ }^{2}$ Dosen Fakultas Ekonomi dan Bisnis Universitas Teknologi Sumbawa \\ ${ }^{3}$ Dosen Fakultas Ekonomi dan Bisnis Universitas Teknologi Sumbawa \\ $1^{\star}$ email: sabiqhilal097@gmail.com \\ 2 email: reza.muhammad.rizqi@uts.ac.id \\ 3email: novadhitya88@gmail.com
}

\begin{tabular}{|c|c|}
\hline & Abstrak \\
\hline Diterima & $\begin{array}{l}\text { This study aims to determine the financial management and business } \\
\text { development applied to Sumbawa Sustainable Forest Honey MSMEs. }\end{array}$ \\
\hline Bulan Juli 2019 & $\begin{array}{l}\text { The analytical method used is a descriptive qualitative method. Technic } \\
\text { analysis consists of three activity lines that occur simultaneously, } \\
\text { namely data reduction by collecting data through interviews with the } \\
\text { informants concerned with research, after that in presenting data }\end{array}$ \\
\hline Diterbitkan & collection of information that has been obtained and then arranged in \\
\hline Bulan Juli 2019 & $\begin{array}{l}\text { accordance with the theoretical foundation used then make conclusions } \\
\text { and taking action, the last is verification of data, in verifying the data } \\
\text { the author uses data triangulation techniques. The results of the study } \\
\text { show how financial management and business development are } \\
\text { implemented by MSMEs, namely the behavior of financial management }\end{array}$ \\
\hline Keywords: & that is still simple, seen from the way the financial records do not meet \\
\hline $\begin{array}{l}\text { Management } \\
\text { and } \\
\text { Development, } \\
\text { Management }\end{array}$ & $\begin{array}{l}\text { the standards, while in developing business opportunities the strengths } \\
\text { and opportunities of MSMEs are quite large, this is seen from the } \\
\text { analysis of IFAS and IFAS factors obtained through SWOT analysis, } \\
\text { after obtaining opportunity points of } 0.80 \text {, threat } 1.20 \text {, strength of } 1.60\end{array}$ \\
\hline Behavior, & and weakness of 1.10 UMKM positions in courtesies diagrams \\
\hline Diversification & $\begin{array}{l}\text { occupying IV quadrant positions namely diversification into strategy } \\
\text { what must be done is to maintain customer or customer satisfaction, by } \\
\text { improving service, quality, promotion and innovation. improve product } \\
\text { quality to compete with other honey. }\end{array}$ \\
\hline
\end{tabular}

\section{PENDAHULUAN}

Pada Usaha mikro kecil menengah (UMKM) mempunyai peran penting dan strategis bagi pertumbuhan ekonomi negara, baik negara berkembang maupun negara maju. Pada saat krisis ekonomi berlangsung di Indonesia, kemampuan UMKM untuk tetap bertahan di masa krisis ekonomi adalah bukti bahwa sektor UMKM merupakan bagian dari sektor usaha yang cukup tangguh. Terdapat tiga alasan yang mendasari negara berkembang belakangan ini, memandang penting keberadaan usaha mikro dan kecil (Berry, et al.,2001). Alasan pertama adalah karena kinerja usaha mikro dan kecil cenderung lebih baik dalam hal menghasilkan tenaga kerja yang produktif. Kedua, sebagai bagian dari dinamikanya, usaha mikro dan kecil sering mencapai peningkatan produktivitasnya melalui investasi dan perubahan teknologi. Ketiga adalah karena sering diyakini bahwa usaha mikro dan kecil memiliki keunggulan dalam hal fleksibilitas ketimbang usaha besar. Sedangkan Sulistyastuti (2004) mengemukakan bahwa di negara-negara maju dan industri baru, UMKM memberikan kontribusi terhadap peningkatan ekspor dan sebagai subkontraktor yang menyediakan berbagai input bagi usaha yang berskala besar sekaligus sumber inovasi. Meningkatnya pertumbuhan UMKM di Indonesia ternyata cukup didominasi oleh industri makanan dan minuman. Beberapa tahun kebelakang, perkembangan bisnis di bidang makanan dan minuman mengalami pertumbuhan yang sangat signifikan. 
Data Dinas Koperasi dan UMKM tahun 2017 menunjukkan total nilai Produk Domestik Bruto (PDB) Indonesia mencapai Rp. 12.840. Miliar seperti terlihat pada tabel 1.1. UMKM memberikan kontribusi sebesar yakni Rp. 7.704 Miliar atau $60,00 \%$ dari total PDB Indonesia. Jumlah populasi UMKM Indonesia pada tahun 2017 mencapai 57,08 juta unit usaha atau 99,99\% terhadap total unit usaha di Indonesia, sementara jumlah tenaga kerjanya mencapai 114.14 juta orang atau 96,99\% terhadap seluruh tenaga kerja Indonesia.

Pengelolaan keuangan dan pengembangan usaha penting untuk diterapkan pemilik UMKM. Menurut Ediraras (2010) bisnis UMKM yang keuangannya dikelola dan diinformasikan secara transparan dan akurat akan memberikan dampak positif terhadap bisnis UMKM itu sendiri. Jika hal ini dapat dilakukan oleh setiap wirausaha, maka besarlah harapan untuk dapat menjadikan usaha yang semula kecil menjadi skala menengah bahkan menjadi sebuah usaha besar.

Langkah-langkah yang harus diterapkan pemilik UMKM supaya UMKMnya dapat berkembang dan maju adalah tidak melibatkan sifat,emosi dan kesukaan individu dalam mengambil keputusan, karena karena dapat mengakibatkan pengambilan keputusan yang salah hal ini biasa disebut behavior manajemen atau perilaku manajemen (Ricciard V. and Simon H,2000). Sedangkan menurut Giltman (2002), manajemen keuangan pribadi merupakan seni dan ilmu mengelola sumber daya keuangan dari unit individu. Dengan demikian, manajemen keuangan pribadi mencakup dua unsur yakni pengetahuan akan keuangan dan seni dalam mengelola. Karena kegiatan mengelola (pengelolaan) membutuhkan kedisiplinan dan menentukan prioritas yang berasal dari pengontrolan diri. Pengontrolan diri akan membantu para pemilik UMKM untuk tetap bertahan pada prinsip manajemen, yakni efesiensi dan efektifitas. Efesiensi, yakni menggunakan sumber-sumber dana secara optimal untuk pencapaian tujuan manajemen keuangan. Sedangkan efektifitas merujuk pada manajemen keuangan pribadi menuju pada tujuan yang tepat.

Peran pemilik UMKM sangatlah dominan dalam menjalankan usahanya. Pemilik UMKM mempunyai tanggung jawab penuh atas usaha yang dijalankannya. Keputusan-keputusan yang bersangkutan dengan UMKM sepenuhnya berada ditangan pemilik. Jadi, seorang pemilik harus mampu mengatasi dan menyelesaikan permasalahan yang timbul dalam UMKMnya dengan mengambil keputusan yang tepat. Pengetahuan tentang pengelolan keuangan dan pengembangan usaha yang baik dapat membantu para pemilik usaha dalam mengambil keputusan-keputusan yang tepat dalam manajemen usahanya, sehingga menghasilkan perilaku manajemen keuangan dan pengembangan usaha yang baik.
Pada kenyataannya selama ini UMKM masih memiliki banyak keterbatasan dan kendala terutama kendala yang terdapat antara UMKM dan perbankan selaku penyalur kredit bagi UMKM. Kelayakan usaha, aspek keuangan, aspek pemasaran dan aspek sumber daya manusia (tenaga kerja) merupakan permasalahan UMKM yang dirasakan selama ini oleh pihak Bank (Bank Indonesia, 2005). masih ada pemilik UMKM yang belum mampu mengelola dan melakukan pengembang usahanya dengan baik, sehingga tidak jarang beberapa UMKM mengalami kegagalan dalam usahanya. Selain beberapa faktor kurangnya kelayakan kegagalan ini dikarenakan masih minimnya pengetahuan pemilik UMKM akan pengelolaan usaha, baik dari segi pengelolaan keuangan pribadi maupun pengembangan usaha. Pengelolaan usaha yang perlu diperhatikan adalah pengelolaan dalam bidang keuangan dan pengembangan usaha yang dilihat dari lingkungan eksternal UMKM yang diperlukan untuk mengetahui faktor-faktor yang dapat memberikan peluang dan ancaman bagi UMKM.

Salah satu UMKM yang ada di Sumbawa adalah Madu Hutan Lestari , "Kabupaten Sumbawa Nusa Tenggara Barat, sangat terkenal dengan madunya yang asli dan melimpah keberadaan madu ini sudah dikenal oleh seluruh masyarakat Indonesia" (www.antvklik.com). Madu dari Sumbawa dikenal dengan ciri khas Madu Hutan alami, dimana madu tersebut diproduksi oleh lebah jenis Apis Dorsata, sejenis lebah berbadan besar penghasil madu yang banyak hidup di hutan Sumbawa. Terkenalnya khasiat madu Sumbawa disebabkan oleh sumber dari madu tersebut yang berasal dari lebah liar yang hanya bisa ditemukan di hutan-hutan Sumbawa. Berdasarkan hasil observasi yang dilakukan pada UMKM ini masih terdapat masalah yang timbul, yaitu pengelolaan usaha yang dilakukan hanya berfokus kepada produktivitas madu, dan mengesampingkan pengelolaan keuangan dan pengembangan usahanya.

Mengetahui pemaparan latar belakang dan hasil observasi tersebut, penulis tertarik untuk mengadakan penelitian mengenai pengelolaan keuangan dan pengembangan UMKM yang diterapkan pada Madu Hutan Lestari Sumbawa. Nantinya hasil dari penelitian ini dapat dijadikan sebagai solusi alternartif dalam melakukan pengelolaan keuangan dan pengembangan UMKM. Oleh karena itu, judul yang digunakan dalam penelitian ini adalah "PENGELOLAAN KEUANGAN DAN PENGEMBANGAN USAHA PADA UMKM MADU SUMBAWA" dengan lokasi penelitian pada UMKM Madu Hutan Lestari Sumbawa.

\section{Rumusan Masalah}

Berdasarkan pembatasan masalah di atas, dapat disimpulkan pokok-pokok permasalahan yang akan dibahas dalam penelitian ini, yaitu: 
1. Bagaimana Pengelolaan keuangan yang diterapkan oleh UMKM Madu Hutan Lestari Sumbawa?

2. Bagaimana Perencanaan Pengembangan Usaha UMKM Madu Hutan Lestari Sumbawa?

\section{LANDASAN TEORI}

\section{Usaha Mikro Kecil dan Menengah (UMKM)}

Usaha Mikro, Kecil, dan Menengah (UMKM) memiliki definisi yang berbeda pada setiap literatur menurut beberapa instansi atau lembaga bahkan undang-undang. Sesuai dengan Undang-Undang nomor 20 tahun 2008 tentang Usaha Mikro, Kecil, dan Menengah, UMKM.

Menurut Hafsah (2004) pengembangan adalah upaya yang dilakukan oleh pemerintah, dunia usaha, dan masyarakat melalui pemberian bimbingan dan bantuan perkuatan untuk menumbuhkan dan meningkatkan kemampuan usaha usaha kecil agar menjadi usaha yang tangguh dan mandiri.

\section{Pengertian Pengembangan Usaha}

Pengembangan dapat diartikan sebagai suatu usaha untuk meningkatkan kemampuan konseptual, teoritis, teknis, dan moral individu sesuai dengan kebutuhan pekerjaan atau jabatan melalui pendidikan dan pelatihan. mengemukakan bahwa pengembangan UKM lebih diarahkan untuk menjadi pelaku ekonomi yang berdaya saing melalui perkuatan kewirausahaan dan peningkatan produktivitas yang didukung dengan upaya peningkatan adaptasi terhadap kebutuhan pasar, pemanfaatan hasil inovasi dan penerapan teknologi. (Afifuddin, 2010).

$$
\text { Pengembangan pasar adalah }
$$
memperkenalkan produk atau jasa saat ini ke wilayah geografis baru (David, 2009). Strategi pengembangan pasar dipilih untuk dijalankan dengan pertimbangan dapat dilakukannya pengkoordinasian, sehingga akan dapat dicapai biaya pengorbanan yang lebih rendah dan resiko yang dihadapi lebih kecil.

\section{Pengelolaan Keuangan}

Manajemen keuangan (pengelolaan keuangan) menurut Horne dalam (Kasmir 2010) adalah segala aktivitas yang berhubungan dengan perolehan, pendanaan, dan pengelolaan aktiva dengan beberapa tujuan menyeluruh. Menurut Hartati (2013) seluruh proses tersebut dilakukan untuk mendapatkan pendapatan perusahaan dengan meminimalkan biaya, selain itu dalam penggunaan dan pengalokasian dana yang efisien dapat memaksimalkan nilai perusahaan.

$$
\text { Fungsi Pengelolaan Keuangan }
$$

(Manajemen Keuangan) Menurut Hartati (2013) menjelaskan bahwa fungsi dari manajemen keuangan (pengelolaan keuangan) adalah:

a. Kegiatan mencari dana (obtain of fund) yang ditujukan untuk keputusan investasi yang menghasilkan laba.

b. Kegiatan mengalokasikan dana (allocation of fund), kegiatan ini ditujukan untuk mengelola penggunaan dana dalam kegiatan perusahaan.

Artinya pemilik sebagai pimpinan dari kelompo usaha harus memiliki pengetahuan dalam mengelola keuangan supaya dapat memaksimalkan kegiatan usaha.

\section{Aspek Keuangan}

Menurut Kasmir dan Jafkar (2012) Aspek Keuangan, menilai biaya-biaya apa saja yang akan dikeluarkan dan seberapa besar biaya-biaya yang akan dikeluarkan. Kemudian meneliti seberapa besar pendapatan yang akan diterima, seberapa lama investasi yang ditanamkan akan kembali, sumber pembiayaan bisnis, dan tingkat bunga yang berlaku). Aspek keuangan menggambarkan proyeksi jumlah dana atau modal awal yang dibutuhkan, sumber modal yang akan digunakan, dan pengembalian apa yang akan diharapkan dari investasi yang dilakukan (Investopedia. 2017).

Menurut Rangkuti (2012), analisis kelayakan aspek keuangan dalam bisnis bertujuan untuk mempelajari hal-hal yang berhubungan dengan aliran kas serta sumber dana dan proyeksi keuangan, baik pemasukan atau pengeluaran yang mungkin terjadi selama masa produksi dan operasional proyek yang direncanakan

\section{Perilaku Manajemen Keuangan}

Perilaku manajemen keuangan dianggap sebagai salah satu konsep penting pada disiplin ilmu keuangan. Banyak definisi yang diberikan sehubungan dengan konsep ini, misalnya, Horne dan Wachowicz (2002) dalam Mien dan Thao (2015) mengusulkan perilaku manajemen keuangan sebagai penentuan, akuisisi, alokasi, dan pemanfaatan sumber daya keuangan. Sedangkan secara keseluruhan Weston dan Brigham (1981) dalam Mien dan Thao (2015) menggambarkan perilaku manajemen keuangan sebagai suatu pengambilan keputusan keuangan, harmonisasi motif individu dan tujuan UMKM. Selain itu menurut Mien dan Thao (2015) manajemen keuangan berkaitan dengan efektivitas manajemen dana. Menurut Amanah (2016), perilaku manajemen keuangan adalah ilmu yang menjelaskan mengenai perilaku seseorang dalam mengatur keuangan mereka dari sudut pandang psikologi dan kebiasaan individu tersebut.

a. Cash flow management

Arus kas adalah indikator utama dari kesehatan keuangan yaitu ukuran kemampuan pelaku UMKM untuk melakukan manajemen arus kas yang baik utamanya adalah dalam hal menyiapkan anggaran.

b. Credit management

Tabungan dapat didefinisikan sebagai bagian dari pendapatan yang tidak dikonsumsi dalam periode tertentu. Ida dan Dwinta (2010) menjelaskan keterampilan keuangan sebagai sebuah teknik untuk membuat keputusan dalam perilaku manajemen keuangan, seperti menyiapkan sebuah anggaran, memilih investasi, memilih rencana asuransi, dan menggunakan kredit adalah contoh dari keterampilan keuangan.

$$
\text { c. Saving behavior }
$$


Saving behaviour adalah kombinasi dari persepsi kebutuhan masa depan, keputusan .

\section{Analisis SWOT}

Analisis SWOT adalah indentifikasi berbagai faktor secara sistematis untuk merumuskan strategi UMKM (Rangkuti, 2014). Analisis ini didasarkan pada logika yang dapat memaksimalkan kekuatan (Strengths) dan peluang (Opportunities), namun secara bersamaan dapat meminimalkan kelemahan (Weaknesses) dan ancaman (Threats). Analisis SWOT merupakan kerangka penganalisisan yang terintegrasi antara internal UMKM dan lingkungan eksternal, dengan membangun pendekatan SWOT (Assauri 2013).

Strategi Pengembangan Usaha Strategi Pengembangan Usaha adalah cara untuk mengantisipasikan masalah-maslah dan kesempatan-kesempatan masa depan pada kondisi perusahaan yang berubah dengan cepat agar sang pengusaha paham dan mengerti tujuan dan fungsi dari kiat mengembangkan usaha kecil itu sendiri.

Diagram kartesius

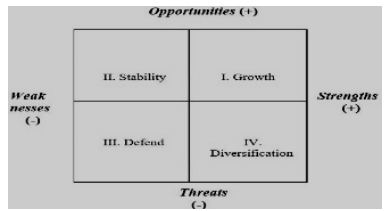

Sumber: Siagian (2005:176)

Cara menentukan kuadran yang tepat, maka perlu dihitung selisih dari subtotal faktor strengths dengan weaknesses (titik pertama) dan selisih dari subtotal faktor opportunities dengan threats (titik kedua). Jika hasil selisih dari subtotal faktor strengths dengan weaknesses adalah positif (+), maka titik pertama akan berada disisi garis horizontal sebelah kanan titik 0. Jika hasilnya negatif (-), maka titik pertama akan berada di sisi garis horisontal sebelah kiri titik 0. Jika hasil selisih dari subtotal faktor opportunities dan threats adalah positif (+), maka titik kedua akan berada di sisi garis vertical di bawah 0 . Akhirnya akan ada dua titik yang nantinya akan menentukan daerah kuadran mana yang harus dipilih untuk mengetahui strategi yang tepat.

\section{METODE PENELITIAN \\ Pendekatan Kualitatif}

Pendekatan yang diterapkan dalam melaksanakan penelitian ini adalah penekatan kualitatif. Creswell menyatakan penelitian kualitatif sebagai suatu gambaran kompleks, meneliti katakata, laporan terinci dari pandangan responden dan melakukan studi pada situasi yang alami. Penelitian kualitatif merupakan riset yang bersifat deskriptif dan cenderung menggunakan analisis dengan pendekatan induktif.

\section{Metode Pengumpulan Data}

Dalam mendapatkan data guna membantu dalam penelitian ini, penulis menggunakan metode pengumpulan data berupa wawancara semi terstruktur yaitu interview membuat garis besar pokok-pokok pembicaraan Peneliti akan memperoleh data primer dengan mencatat melalui catatan tertulis dan melalui perekaman audio tapes dari proses wawancara secara langsung kepada pemilik UMKM Madu Hutan Lestari yaitu Bapak M. Junaidi Zain, Bendahara Ibu Jun, Pembina Bapak Yudis.

\section{Teknik Analisa Data}

Teknik analisis data yang digunakan dalam penelitian ini adalah analisis interaktif. Model ini ada 4 komponen analisis yaitu: pengumpulan data, reduksi data, penyajian data, dan penarikan kesimpulan. Data dalam penelitian kualitatif, diperoleh dari berbagai sumber dengan menggunakan teknik pengumpulan data yang bermacam-macam (triangulasi), dan dilakukan secara terus menerus hingga data mencapai titik jenuh (Sugiyono, 2001).

\section{Pengecekan Keabsahan Temuan}

Trianggulasi adalah cara yang paling umum digunakan dalam penjaminan validitas data dalam penelitian kualitatif. Trianggulasi merupakan teknik pemeriksaan keabsahan data dengan memanfaatkan sesuatu yang lain diluar data itu untuk keperluan pengecekan data atau sebagai pembanding terhadap data itu.

\section{HASIL DAN PEMBAHASAN}

Nama UMKM : Madu Hutan Lestari

Lokasi : Dusun Batu Dulang, RT 1/2 Desa Batu Duang, Kec. Batu Lanteh

UMKM Madu Hutan Lestari berdiri pada tahun 2000, memiliki latar belakang ingin menjaga kelestarian hutan melalui budidaya madu hutan. Merupakan salah satu UMKM Madu yang telah lama berdiri beranggotakan 60 orang pemburu madu dan 10 orang bagian pengemasan dan pemasaran UMKM ini mulai dikenal oleh masyarakat sumbawa dan dijadikan contoh UMKM madu lainya karena berdiri paling awal, UMKM ini juga menjadi salah satu Founder Jaringan Madu Hutan Sumbawa (JMHS) yakni kumpulan pengusaha madu hutan yang ada di Sumbawa, berikut merupakan kutipan wawancara yang dilakukan dengan pemilik UMKM saat di lokasi

\section{Pengembangan Usaha}

Pengertian pengembangan usaha dapat disimpulkan bahwa segala sesuatu yang dilaksanakan untuk memperbaiki pelaksanaan pekerjaan yang sekarang maupun yang akan datang memberikan informasi, pengarahan, pengaturan, dan pedoman dalam pengembangan usaha.

Pengembangan yang dilakukan oleh UMKM Madu hutan Lestari dalam kurun waktu lima tahun kebelakang adalah memperluas jaringan pemasaan produk dengan melakukan kerjasama dengan 
Jaringan Madu Hutan Sumbawa (JMHS), langkah ini mempermudah pemilik untuk melakukan promosi dan perluasan pasar, tentunya dalam menjalin kerjasama dengan JMHS pemilik dituntut untuk mengupgrade kualitas produk mulai dari menjaga keaslian bahan baku dan pengemasan atau pelabelan supaya merek dari produk Madu Hutan Lestari.

\section{Pengelolaan Keuangan}

Tempat produksi di desa Batu Dulang agak jauh dari perkotaan tapi strategis bagi para pemburu yang melakukan perburuan madu di hutan desa Batu Dulang, kendati demikian UMKM juga memiliki rumah madu yang bekerjasama dengan JMHS yang berlokasi di kota Sumbawa. Dalam waktu dekat BRI yang memiliki program bina desa di Batu Dulang akan membuka galeri sekaligus cafe yang berlokasi dekat dengan rumah produksi, hal ini menjadi peluang bagi UMKM untuk memasarkan produk di galeri tersebut.

\section{Aspek Keuangan}

Aspek Keuangan, menilai biaya-biaya apa saja yang akan dikeluarkan dan seberapa besar biayabiaya yang akan dikeluarkan. Kemudian meneliti seberapa besar pendapatan yang akan diterima, seberapa lama investasi yang ditanamkan akan kembali, sumber pembiayaan bisnis, dan tingkat bunga yang berlaku). Sedangkan sumber dana yang dapat dari Bank BRI sebagai pembina UMKM dan persediaan awal dari pemilik.

\section{Perilaku Manajemen Keuangan}

Arus kas adalah indikator utama dari kesehatan keuangan yaitu ukuran kemampuan pelaku UMKM untuk melakukan manajemen arus kas yang baik utamanya adalah dalam hal menyiapkan anggaran. Arus Kas yang dipahami oleh pemilik adalah pencatatan biaya yang dikeluarkan untuk produksi dan pendapatan yang didapatkan dari hasil produk.

Keuangan UMKM dikelola oleh pemilik dimana aktivitas keuangan dengan melakukan metode pembukuan secara manual dengan menggunakan pencatatan cash flow, mengurus nota penjulan dan nota pembelian. Penghasilan yang diperoleh UMKM adalah dari penjualan produk madu, sedangkan pengeluaran UMKM meliputi gaji karyawan setiap bulan, bonus kerja, biaya tidak terduga, biaya produksi dan operasional, dan pembelian bahan baku. Karena pencatatan arus kas UMKM masih dilakukan secara manual maka tidak jarang ditemukan ketidaktelitian dalam proses pembukuan. Oleh karena itu untuk kedepannya UMKM merencanakan untuk menggunakan metode pencatatan yang rapi.

tabungan dan tindakan penghematan. Disisi lain, orang cenderung mendefinisikan tabungan sebagai investasi, menempatkan uang di rekening bank, berspekulasi dan melunasi hipotik (Warneryd,1999).

\section{Analisa lingkungan Internal dan Eksternal}

Berdasarkan hasil analisa pada lingkungan internal dan lingkungan eksternal diatas, peneliti mendapatkan beberapa kekuatan, kelemahan, peluang dan ancaman yang ada pada UMKM.

\section{Tabel 1.}

Matriks SWOT

\section{Strategi Alternatif}

Strategi (SO)

1. Meningkatkan omset penjualan dengan

\begin{tabular}{|c|c|c|}
\hline & 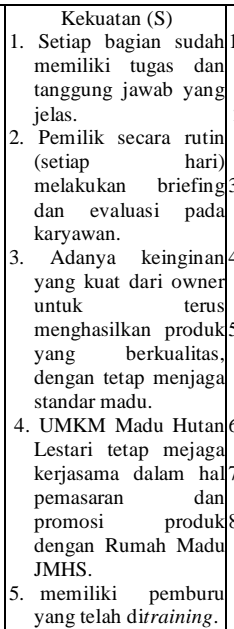 & $\begin{array}{l}\text { Kelemahan (W) } \\
\text { 1. Pencatatan keuangan } \\
\text { yang kurang rapi dan } \\
\text { mumpuni } \\
\text { 2. Belum ada divisi atau } \\
\text { bagian khusus } \\
\text { pemasaran. } \\
\text { Penetapan harga } \\
\text { bergantung } \\
\text { kompetitor. pada } \\
\text { 4. Belum ada SOP tertulis } \\
\text { atau peraturan tertulis } \\
\text { bagi karyawan.. } \\
\text { 5. Analisa konsumen atau } \\
\text { pengunjung hanya } \\
\text { dilakukan melalui } \\
\text { pegamatan. } \\
\text { Inovasi produk yang } \\
\text { masih kurang } \\
\text { 7. Letak rumah produksi } \\
\text { yang jauh dari kota. } \\
\text { kemasan yang yang } \\
\text { masih rawan (fragile) } \\
\end{array}$ \\
\hline \begin{tabular}{|l|}
\multicolumn{2}{|c|}{ Kesempatan (O) } \\
1. Pasar masih besar ditandai \\
dengan pertumbuhan \\
konsumen madu. \\
2. Adanya pasar baru yang \\
belum disentuh oleh \\
UMKM yakni produk- \\
produk sampingan seperti \\
inovasi madu jahe bubuk \\
atau inovasi yang lainya. \\
3. Banyak media atau \\
saluran promosi yang low \\
budget seperti social \\
media (facebook, \\
twitter,Instagram) dan \\
brosur. \\
4. Kekuatan tawar-menawar \\
konsumen terhadap madu \\
tergolong kecil. \\
5. Adanya wisata yang \\
dikembangkan oleh desa \\
supaya para pengunjung \\
dapat membeli oleh-oleh \\
di lokasi rumah produksi \\
6. Terbentuknya kerjasama \\
bina desa dengan \\
instansi Perbankan \\
untuk meningkatkan \\
mutu dan kualitas \\
produk
\end{tabular} & \begin{tabular}{|l|} 
Strategi (SO) \\
1. Meningkatkan omset \\
penjualan dengan \\
meningkatkan \\
pelayanan terhadap \\
konsumen/pengunjun \\
g. (S1,S3,S5,O1,O2) \\
2. Meningkatkan omset \\
penjualan dengan \\
mengkomunikasikan \\
standar bahan dalam \\
promo dan desain. \\
(S3,S5,O1,O2,O3) \\
3. Meningkatkan omset \\
dari wisatawan yang \\
datang berkunjung ke \\
objek wisata alam ( \\
Batu \\
(S3,O5,O6) Dulang \\
\\
\end{tabular} & 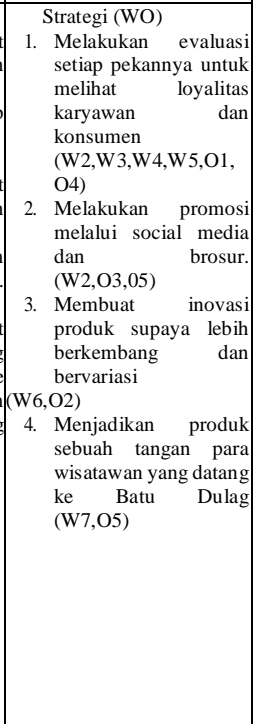 \\
\hline \begin{tabular}{|l|} 
Ancaman (T) \\
1. Banyak pendatang dalam \\
bisnis madu baru yang \\
bermunculan \\
Sumbawa. \\
2. Banyak Pemburu madu \\
yang belum terlatih \\
sehingga mengganggu \\
ekosistem lebah \\
3. Usaha kompetitor \\
terkonsep dengan baik \\
(secara outlet dan desain) \\
4. Kompetitor-kompetitor \\
banyak yang melakukan \\
pencampuran madu \\
dengan gula menurunkan \\
standar madu sumbawa \\
5. Madu sebagai \\
sumberdaya alam yang \\
tidak dapat direkayasa
\end{tabular} & \begin{tabular}{|l|} 
Strategi Ancaman (ST) \\
1. Menjagar kepuasan \\
konsumen, dengan \\
cara meningkatkan 2 \\
pelayanan, kualitas, \\
promosi dan inovasi. \\
(S3,S4,S5,T1,T2,T3,T \\
4) \\
\end{tabular} & $\begin{array}{l}\text { Strategi WT } \\
\text { Merekrut bagian } \\
\text { pemasaran (W2,T2,T4) } \\
\text { 2. Merealisasikan produk } \\
\text { invasi (W4, T1) } \\
\end{array}$ \\
\hline
\end{tabular}


meningkatkan pelayanan terhadap konsumen/pengunjung. (S1,S3,S5,O1,O2)

2. Meningkatkan omset penjualan dengan mengkomunikasikan standar bahan dalam promo dan desain. (S3,S5,O1,O2,O3)

3. Meningkatkan omset dari wisatawan yang datang berkunjung ke objek wisata alam Batu Dulang (S3,O5,O6)

Strategi (WO)

1. Melakukan evaluasi setiap pekannya untuk melihat loyalitas karyawan dan konsumen (W2,W3,W4,W5,O1,O4)

2. Melakukan promosi melalui social media dan brosur. (W2,O3,05)

3. Membuat inovasi produk supaya lebih berkembang dan bervariasi

4. (W6,O2)

5. Menjadikan produk sebuah tangan para wisatawan yang datang ke Batu Dulag (W7,O5)

Strategi Ancaman (ST)

1. Menjaga kepuasan konsumen, dengan cara meningkatkan pelayanan, kualitas dan promosi. (S3,S4,S5,T1,T2,T3,T4)

Strategi (WT)

1. Merekrut bagian pemasaran (W2,T2,T4)

2. Merealisasikan produk inovasi (W4, T1)

\section{Analisis Faktor Internal dan Eksternal}

Diagram Kartesius SWOT Berdasarkan tabel 3 Matriks IFAS dari UMKM Madu Hutan Lestari, diperoleh hasil bahwa nilai skor untuk faktor kekuatan adalah 1,6 dan nilai skor untuk faktor kelemahan adalah 1,10. Sementara itu, berdasarkan tabel 4 Matriks EFAS dari UMKM Madu Hutan Lestari, diperoleh hasil bahwa nilai skor untuk faktor peluang adalah 0,80 dan nilai skor untuk faktor ancaman adalah 1,2. Nilai skor kekuatan ternyata diatas nilai skor kelemahan dengan selisih nilai $(+)$ 0,50 , sedangkan nilai skor peluang ternyata di bawah nilai skor ancaman dengan selisih nilai (-)0,40 .

Diagram Kartesius

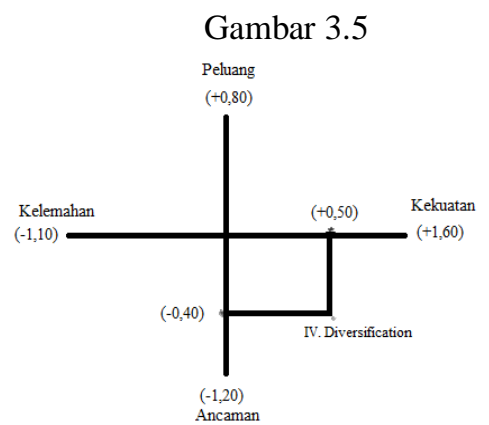

Dari hasil identifikasi seluruh faktor internal dan eksternal serta penentuan selisih nilai skor, kemudian digambarkan dalam diagram kartesius SWOT, dimana faktor kekuatan dan peluang diberi nilai positif $(+)$, selain itu faktor kelemahan dan ancaman diberi nilai negatif (-). Diagram kartesius SWOT bisa dilihat pada gambar
3. Berdasarkan diagram kartesius SWOT pada gambar 3, dapat dilihat bahwa UMKM Madu Hutan Lestari berada pada kuadran IV yang berarti bahwa strategi yang digunakan adalah strategi Strengths Threats (ST) yang juga disebut sebagai strategi Diversification. Dari hasil penelitian yang dilakukan, Madu Hutan Lestari berada pada kuadran IV yakni kuadran Diversification yang juga disebut sebagai strategi ST yang menggunakan kekuatan yang dimiliki untuk mengatasi segala ancaman yang ada, sehingga yang dapat dilakukan UMKM Madu Hutan Lestari adalah Menjaga kepuasan konsumen, dengan cara meningkatkan pelayanan, kualitas, promosi dan inovasi.

Meningkatkan kualitas produk agar dapat bersaing dengan UMKM madu lain. Selain itu divisi keuangan atau bendahara harus melakukan pencatatan arus kas dengan baik dan melakukan penghitungan harga pokok produksi karena divisi keuangan memiliki keterlibatan dalam tujuan jangka pendek dan jangka panjang perusahaan, karena divisi keuangan akan membantu perusahaan dalam membuat anggaran perencanaan untuk merealisasikan tujuan tersebu

\section{KESIMPULAN DAN SARAN}

Kesimpulan

1. Perilaku manajemen keuangan yang diterapkan oleh UMKM masih sangat sederhana yakni hanya ada pencatatan uang masuk dan uang keluar dan masih belum mengguakan kaidah-kaiadah pencatatan arus kas yang baik dan benar, sedangkan bila dilihat dari aspek keuangannya pemilik sudah mengetahui apa itu manajemen kredit dan perilaku penyimpanan dana untuk keadaan yang tidak terduga.

2. Pengembangan usaha yang haus diterapkan oleh UMKM Madu Hutan Lestari yakni diversification strategy. Maksudnya UMKM harus menjaga kepuasan konsumen, dengan cara meningkatkan pelayanan, kualitas, promosi dan inovasi supaya dapat meningkatkan keuntungan dan tercapainya tujuan investasi.

Saran

1. Agar pemilik lebih memperhatikan perilaku manajemen keuangan yang baik dan benar sehingga dalam berjalanya usaha akan terhindar dari kesalah pemahaman, Seperti merapikan pencatatan arus kas yang benar dan rapi, serta memiliki perencanaa keuangan di masa mendatang supaya invesatasi yang dilakukan mendapat pengembalian yang diinginkan.

2. merekrut tenaga kerja dibagian pemasaran, karena belum ada divisi atau bagian khusus pemasaran. Tenaga kerja dibagian pemasaran sangat penting untuk melakukan 
promosi, sehingga masyarakat bisa lebih mengetahui keberadaan Madu Hutan Lestari. Tenaga kerja dibagian pemasaran juga dapat meningkatkan jumlah pelanggan, selain itu juga divisi pemasaran dapat melakukan inovasi produk dengan mengubah model packaging .

\section{REFRENSI}

Amanah,Ersha. (2016) berjudul "Pengaruh Financial Knowledge, Financial Attitude dan External Locus of Control terhadap Personal Financial Management Behavior pada Mahasiswa S1 Universitas Telkom".Skripsi. Universitas Telkom.

Assauri, S. 2008. Manajemen Produksi dan Operasi. Edisi revisi : Fakultas Ekonomi Universitas Indonesia. Jakarta

Assauri, S. 2013. Strategic Management Sustainable Competitive Advantages. PT raja Grafindo Persada. Jakarta.

AY Lubis, Pengembangan Usaha, repository.usu.ac.id $>$ bitstream, pdf, h. 9 .

Berry, A., Rodriquez, E. \& Sandeem, H. (2001).Small and medium enterprises dynamics in Indonesia.Bulletin of Indonesian Economic Studies,37(3),363-384.

Brigham, E., \& Houston, J. 2009. Fundamentals of Financial Management (12 ed.). USA: Soth Western.

David, F. R. 2005. Manajemen Strategis. Penerjemah : Salemba Empat. Terjemahan dari : Strategic Management. Jakarta.
David, F.R. 2009. Manajemen Strategis. Jakarta: Salemba Empat .

David, F. R. (2009). Manajemen strategi. Edisi Kesepuluh. Jilid 1. Jakarta: Salemba Empat.

Ediraras, Dharma. 2010. Akuntansi dan Kinerja UMKM. Jurnal Ekonomi Bisnis Nomor 2, Volume 15.

Hafsah, M.J. 2004. Upaya Pengembangan Usaha Kecil dan Menengah (UKM). Jurnal Infokop Nomor 25 Tahun XX

Hartati, Sri. 2013. Manajemen Keuangan Untuk Usaha Mikro, Kecil dan Menengah. www.apipwu.com/wpcontent/uploads/2013/01/ArtikelSriHartati.pdf.

Hunger, D, J dan T. L Wheelen. 2001. Manajemen Strategis. ANDI : Yogyakarta.

Hubeis. Musa. 2009. Prospek Usaha Kecil dalam wadah Inkubator Bisnis, Ghalia Indonesia, Jakarta.

Ida, \& Dwinta, C. Y. (2010). Pengaruh Locus of Control, Financial Knowledge, Income Terhadap Financial Management Behavior . Jurnal Bisnis dan AKuntansi , 131144.

Kasmir. (2011). Kewirausahaan. Jakarta: PT Raja Grafindo.

Kasmir. 2010. Pengantar Manajemen Keuangan. Jakarta: Prenadamedia Group.

Kementerian Koperasi dan UKM. 2016. Situs web www.depkop.go.id 
Kementerian Koperasi dan UKM. Draf Rencana Strategis Pembangunan Koperasi dan UMKMPeriode Tahun 2005 - 2009. Jakarta, 2004. LPPI, Bank Indonesia. (2015). Profil Bisnis Usaha Mikro, Kecil dan Menengah (UMKM). Jakarta.

Mangkuprawira, Syafry. 2002. Manajemen Sumber Daya Manusia Strategi. Jakarta : Ghalia Indonesia.

Moleong, L. J. (2005). Metode penelitian kualitatif. Edisi Revisi. Bandung: PT Remadja Rosdakarya.

Mien Nguyen Thi Ngoc, Thao Thran Puong. 2015. Factors Affecting Personal Financial Management Behaviors : Evidence from Vietnam.Proceedings of the Second AsiaPacific Conference on Global Business, Economics, Finance and Social Sciences (AP15Vietnam Conference).

Pandji Anoraga, Ekonomi Islam Kajian Makro dan Mikro, (Yogyakarta: PT. Dwi Chandra Wacana 2010), hal. 32

Panji Anoraga, Manajemen Bisnis, RINEKA CIPTA, Jakarta, 2009, hlm. 50

Phung,Albert.(2016). Behavioral Finance: Introduction. Tersedia [Online]. http://www.investopedia.com/unive rsity/behavioral_finance/. Diakses pada 01 Juni 2017.

Rangkuti, F. (2008). Analisis SWOT teknik membedah kasus bisnis, Jakarta: Gramedia PustakaUtama.

Rangkuti, F. (2009). Analisis SWOT: Teknik Membedah Kasus Bisnis.
Penerbit: PT Gramedia Pustaka Utama. Jakarta

Ricciard V. \& Simon, H, K. 2000. What is Behavior in Finance. Bussines Education Technology. Vol.22, No.7.

Sugiyono. (2010). Metode Penelitian Pendidikan. Bandung: Alfabeta

Sugiyono. (2011). Metode Penelitan Kuantitatif, Kualitatif, dan R \& D. Bandung: Alfabeta

Solihin, Ismail (2009). Pengantar Manajemen. Jakarta: Erlangga.

Tabel pertumbuhan Uasaha Mikro Kecil Menengah Tahun 2017 bersumber dari website http://www.depkop.go.id/

Tjiptono, Fandy. 2008. Strategi Pemasaran. Yogyakarta: Penerbit Andi.

Undang-Undang No. 20 Tahun 2008 tentang Usaha Mikro, Kecil dan Menengah

Xiao, J.J, \& Dew, J. (2011). The financial management behavior scale: development and validation. Journal of Financial Counseling and Planning Education. 